Egyptian Journal of Aquatic Biology \& Fisheries

Zoology Department, Faculty of Science,

Ain Shams University, Cairo, Egypt.

ISSN $1110-6131$

Vol. 25(3): 1079 - 1093 (2021)

www.ejabf.journals.ekb.eg

\title{
Observation of behavior and daily activity of the mud crab, Scylla serrate (Forskal, 1775) under control condition
}

\section{Indra Junaidi Zakaria*, Deka Agustina Saragih}

Biology Department, Faculty of Mathematics and Natural Sciences, Andalas University, Limau Manis, Padang, West Sumatra - 25163, Indonesia.

*Corresponding author: indrajunaidi@sci.unand.ac.id

\begin{tabular}{l}
\hline ARTICLE INFO \\
Article History: \\
Received: May 4, 2021 \\
Accepted: June 11, 2021 \\
Online: June 30, 2021
\end{tabular}

Keywords:

Behavior patterns,

Daily activity,

Mangrove,

Scylla serrata,

Under control condition

\section{ABSTRACT}

In the mud crab, Scylla serrate (Forskal, 1775) cultivation, the adult crab behavior patterns, such as daily and reproductive activities, need to be addressed and determined, especially under control conditions. This information can be used to plan mud crab hatcheries intensively. Thus, the current research was carried out to discover the behavior and daily activity of the mud crab ( $S$. serrata) under control conditions. A survey was conducted using observation technique and systematic recording towards some behavior phenomenon of used 4 (four) adults of the mud crab comprised one big and small males; one big and small females, observed in an aquarium with a volume of $1.5 \times 1 \times 1 \mathrm{~m}^{3}$. The data obtained were tabulated in the form of tables and graphs, then described. The result showed that, the daily activity of the mud crab from the highest to the lowest was the repose (resting) activity $(51,88 \%)$, followed by the movement $(45,70 \%)$, the agonistic activity $(2,30 \%)$, and the lowest activity was represented by feeding $(0,12 \%)$, respectively. The reproductive activity was not found until copulation and was only observed during seduction and mutual running.

\section{INTRODUCTION}

Mud crab, Scylla serrate (Forskal, 1775) is a crab species that lives in a mangrove habitat and a commodity export beside blue swimming crab, Portunus pelagicus (Linnaeus, 1758). Blue swimming crab has essential economic value as meat in canned or in freeze food, while mud crab can be marketed in live condition because it is more resistant to live outside of water (Efrizal et al., 2018; Zakaria and Selasih 2018). Furthermore, people enjoy eating mud crab and other crustaceans due to their good taste and containing high nutrition (Kasry 1991; Catacutan 2002; Lubis et al., 2021).

Mud crabs have economic value in several countries, such as Australia, Japan, Indonesia, Taiwan, and the Philippines. These countries make mud crab one of the production targets in their fishery activities (Watanabe et al., 1996; Cristensen et al., 2004; Ward et al., 2008). According to Cholik (1999), mud crab fisheries in Indonesia were obtained from natural capture in the coastal waters, especially in mangrove or estuary forests, and from aquaculture in brackish water. With the increasing demand for crab 
fisheries in international markets, the catching of mud crab has also increased leading to a decrease in abundance and size.

Though efforts were exerted to limit the capture of mud crab from natural resources $\mathrm{c}$ by fishermen and other stakeholders through the management of sustainable mud crab capture, the development of mud crab cultivation is a must (Gufron and Kordi 2005; Efrizal et al., 2018; Zakaria and Selasih 2018). In cultivation, many factors can be obstacles, such as the number, size, and stock of the seeds. Besides, to ensure market stability for local and global production, a reliable and stable production amount is one of the main requirements. The most important is the basic knowledge of behavior patterns such as daily and reproductive activities used as an intensive development of mud crab cultivation under control conditions (Efrizal et al., 2018).

Some other research in Indonesia reported on aquaculture activity with the controlled condition was those conducted by Efrizal (2009). It was about the observation period of ovipositional and multiple spawning of blue swimming crab P. pelagicus in controlled condition. Yulita (2011) also studied the reproductive behavior of blue swimming crab Portunus pelagicus (Linnaeus, 1758) under control conditions. The result of this study is that the daily activity of the blue swimming crab generally spends more time to rest (50.50\%), next comes the movement activity (31.3\%), followed by agonistic activity represented by fighting (10.07\%), reproductive activity $(7.13 \%)$, and feeding $(1.16 \%)$.

The activity of mud crab ( $S$. serrata) cultivation has a relation with the behavior patterns of the adult individuals of this species. However, information and studies about its behavior patterns, such as daily and reproductive activities, as based information for mud crab cultivation in the laboratory scala are still limited.

\section{MATERIALS AND METHODS}

\section{Research materials:}

The research materials were an aquarium with volume $1.5 \times 1 \times 1 \mathrm{~m}^{3}, \mathrm{pH}$ meter, camera, digital measure, stopwatch, hand refractor-salinometer, digital thermometer, label paper, tissue, observation table, and accessories. Furthermore, there were 4 (four) adults of variable size of mud crab represented by two males (big and small) and two females (big and small) as shown in Table (1). Then, mud, gravel, mangrove leaves, and brackish water were added as a habitat for mud crab, while shells and fresh pieces of fish were added as natural food.

Table 1. Length and weight of mud crab (Scylla serrata) used in this experiment

\begin{tabular}{lcc}
\hline Individuals & Length $(\mathbf{m m})$ & Weight $($ gram) \\
\hline Big male (BM) & 180 & 600 \\
Big female (BF) & 150 & 500 \\
Small male (SM) & 160 & 450 \\
Small female (SF) & 130 & 400 \\
\hline
\end{tabular}




\section{Research method}

This study was conducted with a survey method. A visual technique was used and a systematic observance of any behavior in the aquarium was noted. Eventually, all the results were presented in Tables and graphs and then were fully described.

\section{Mud crab maintenance}

Two males and two females mud crabs were cleaned and put in an aquarium $(1.5 \times 1 \times 1$ $\left.\mathrm{m}^{3}\right)$. The aquarium was filled with mud, gravel, and brackish water around $15 \mathrm{~cm}$ from the ground. Mud and gravel were placed at the bottom of the aquarium with different shapes and heights, like the substrate in nature. The monitoring was done daily, and the mud crabs were fed from 5.00 until $6.00 \mathrm{pm}$ as long as maintenance. They were fed on pieces of fresh-cut fish with a size of $1-3 \mathrm{~cm}$ more or less $10 \%$ of all individuals' mud crab's total weight.The remaining food was weighed and discarded every morning.

\section{Observation on behavior and daily activity of mud crab}

Observations were done at a distance of around $\pm 1 \mathrm{~m}$ from the ground aquarium. Quantitative data were noted with continuous sampling, and an observation period of 168 hours was specialized to determine the frequency of each activity. Periods of observation were: morning, pre-afternoon, last afternoon, evening, pre-midnight, and midnight. The observations were conducted for 24 hours every day for seven days. For the afternoon period, it was divided into three different times; from 6.00 - $10.00 \mathrm{am}, 10.00 \mathrm{am}-2.00 \mathrm{pm}$, and from 2.00 - $6.00 \mathrm{pm}$. On the other hand, the evening was divided into three different times; from $6.00-10.00 \mathrm{pm}$, $10.00 \mathrm{pm}-2.00 \mathrm{am}$, and from $2.00-6.00 \mathrm{am}$. The observations of behavior were resting, moving, agonistic, feeding, and reproduction.

\section{The measurement of physical and chemical water properties:}

The measurements of physical and chemical water propreties were conducted every hour throughout the observation period. The physical and chemical factors measured were as follows: temperature using a digital temperature, water acidity ( $\mathrm{pH}$ digital), and salinity (hand refracto-salinometer).

\section{RESULTS AND DISCUSSION}

\section{Behavior and daily activity of mud crab}

During the observation, behaviors of all activities of mud crabs (resting, moving, agonistic, feeding, and reproducing) could be observed clearly. However, the reproductive activity was not found until copulation; it was observed only during seduction and mutual running. Big male (BM) was observed usually near the big female (BF) and circled the female in its reaching area. This behavior means that the big male (BM) decided on the mate. Crabs were observed running towards each other and this occurred during seduction. On the other hand, the small male (SM) did not achieve any activity onto the other female crab. When a small male (SM) did accidentally approach a big female (BF), the big male (BM) would attack with widely openened claws. Schoene (1968) stated that the fighting activity betweem males occur due to the attempt of one male to take the territory and female of the other. 
Mud crabs spend most of their time resting, recording a value of $51.88 \%$. While, its movement was estimated by around $45.70 \%$, followed by agonistic (fighting) $2.30 \%$, whereas the lowest was the percentage of the feeding activity (around 0.12\%) (Fig. 1).

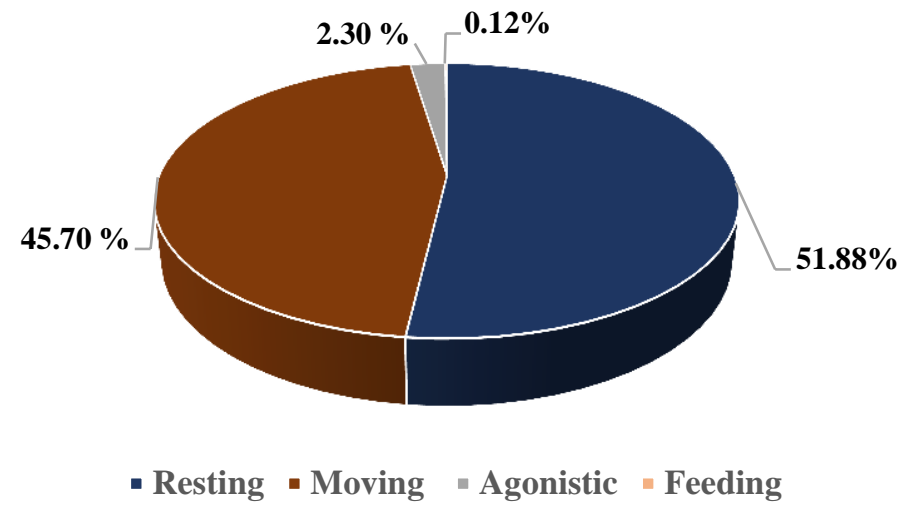

Fig. 1. Percentages of all crab activities.

Fig. (2) shows that the highest activity based on daily observations was resting activity and was found on the first day $(55.47 \%)$. The lowest rest occurred on the fifth day with a value of $49.69 \%$. The next high activity was the moving activity which increased from the second day to the seventh day, whereas the most increased activity occurred on the fifth day $(48.13 \%)$. In the limited container (aquarium), the mud crab did something outside their usual activity, like raising part of his body to the wall container and then moving slowly. It was happening because the crab was trying to get out of the container. According to Yulita (2011), limited space in the container for cultivation and the frequency of intensive interactions can attract a male individual of blue swimming crab ( $P$. pelagicus) who desires to carry activities out of character.

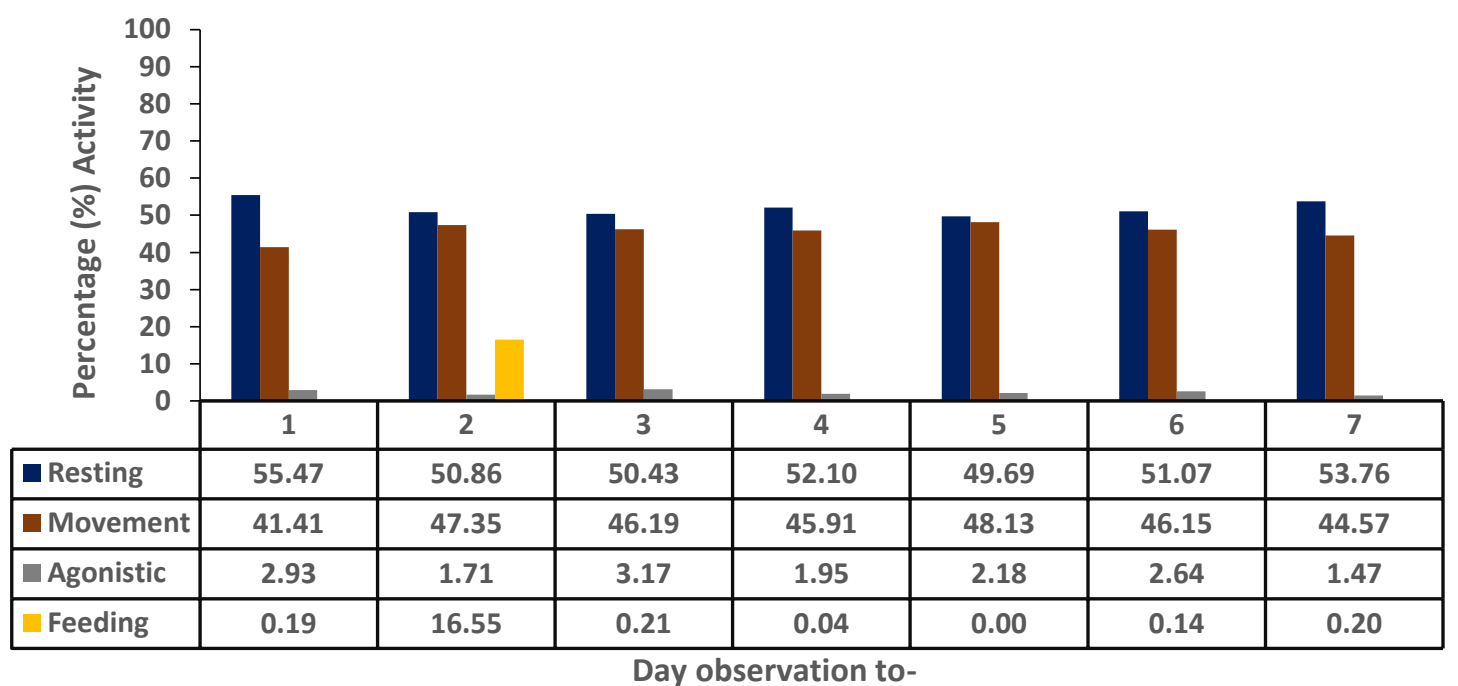

Fig. 2. Percentages of mud crab daily activities. 
Furthermore, the agonistic activity came in the third order and was represented by the highest activity on the third day $(3.17 \%)$. The feeding activity came in the last, and reached the highest on the third day $(0.21 \%)$, while on the fifth day, mud crab was not active at all (Fig. 2). Feeding activity was high on the third day because the agonistic activity also occurred on the same day. The agonistic movement requires energy that crabs get through nutrition. Similarly, the blue swimming crab would eat up all the food (Yulita 2011) when given during agonistic or reproduction activity.

The percentages of activities of mud crab were hourly recorded and all observations are shown in Fig. (3). The rest-activity rate was the higher at $10.00 \mathrm{am}-2.00 \mathrm{pm}$ (57.21\%), while the lower was detected at $10.00 \mathrm{pm}-2.00 \mathrm{am}(48.23 \%)$. During the daytime, the mud crabs were found resting inside the sandy mud substrate. The frequency of activities increased when environmental conditions were suitable for starting the movement. Weather factors affected the mud crabs' movement rate; cloudy and rainy weather supported movement actively. As the sun moves from the evening to the night, the mud crabs moved actively and ended their resting time.

The percentages of moving were higher at $10.00 \mathrm{pm}-2.00 \mathrm{am}(48.23 \%)$ and lower at $10.00 \mathrm{am}-2.00 \mathrm{pm}$ afternoon (41.70\%); while agonistic activity became higher at $10.00 \mathrm{pm}$ $2.00 \mathrm{am}(3.37 \%)$ and lower at $10.00 \mathrm{am}-2.00 \mathrm{pm}(1.09 \%)$. Agonistic frequency was increasing because a competition was assumed to take place to protect the female. Feeding activity got higher percentages at $6.00-10.00 \mathrm{pm}(0.41 \%)$ and lower at noon and afternoon $(0 \%)$. According to Schoene (1968) and Hazlett (1972), attacking among blue swimming crabs occurs to seize either food, mates or others. Thus, the reproductive activity in taking a mate also affects the feeding and mud crab movement frequency.

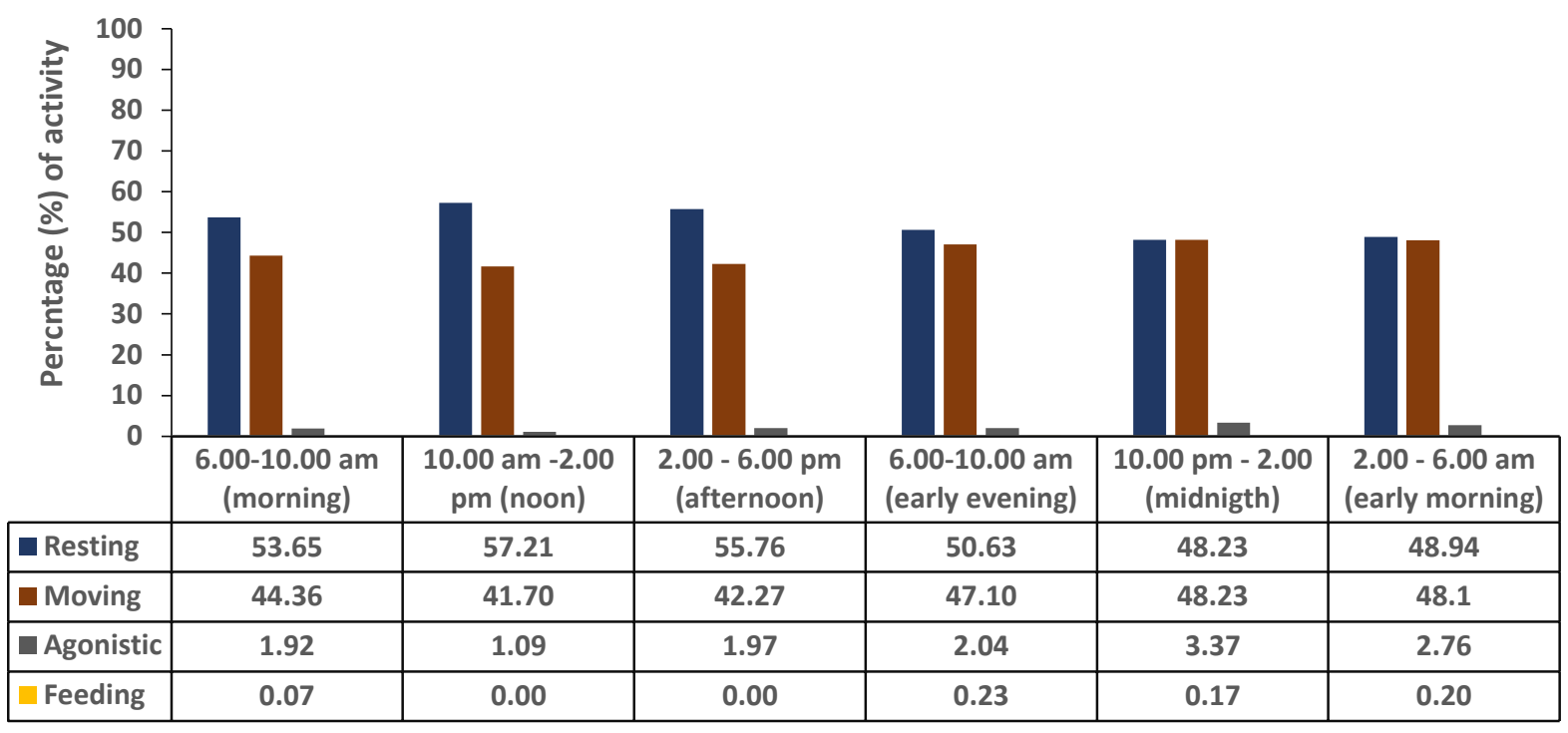

Fig. 3. Percentages of activities of mud crab every hour observation. 


\section{Resting Activity}

The resting forms of the mud crab were represented by drowing or burrowing in the mud and the sand, standing on the surface, or hiding with protruding several body parts such as carapace, antennae, eyes, and stretched claws (Fig. 4). The same conditions are also found in the resting stage of the fiddler crab (Uca terpsichores) and other brachyuran crabs to detect and manipulate predators by burying themselves and stretching the claws in the substrate, and slightly sticking out their eyes to monitor them (Layne et al. 2003; Ribeiro et al., 2006; Christy 2007).

Rest buried in the sand began by digging and sliding the sandy substrate using swimming feet, followed by carapace movements from behind and other bodies until the body was fully immersed. For mud crabs, resting is not only for sleeping but also for pausing from other activities. After feeding, fighting and moving, mud crabs stopped to rest for a few minutes. When they were resting to sleep, mud crabs prepared their position in such a way and as comfortable as possible, chose a slightly hidden place, had more substrate, then dug the sand by moving the swimming leg and submerging the back of the body. On the other hand, during resting which is not targetting to sleep, they stopped suddenly from walking and then stayed in one corner of the aquarium while swimming, quiescent for a few moments without immersing themselves, and swam back to another corner.

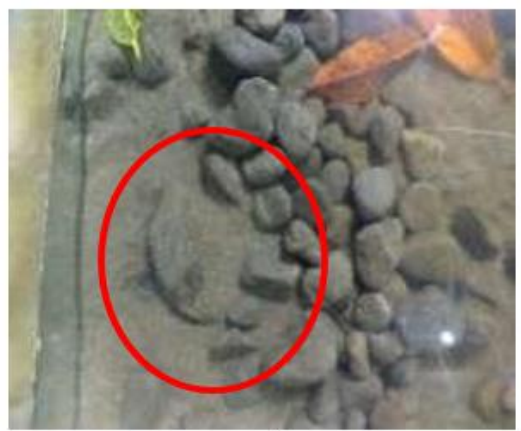

A

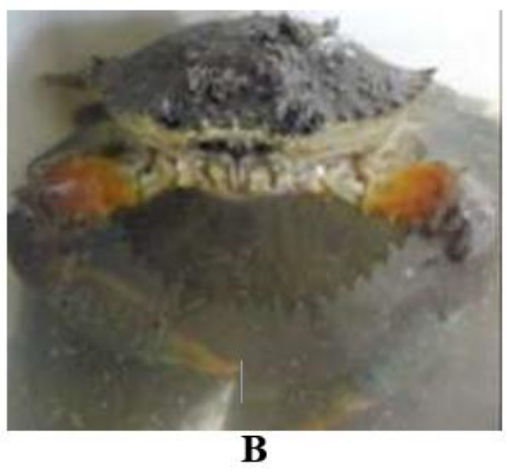

B

Fig. 4. (A) Resting with drowning oneself, and (B) Resting on the surface.

\section{Moving Activity}

The mud crabs moved for different purposes, the most typical of which was selfprotection and vigilance. Although buried in a sandy mud substrate, the mud crabs would bulge and widen their claws as a survival and precaution sign. According to Innocenti et al. (1998), the moving activities of mud crab are for resting, searching, caring, laying eggs, digging nests, burying oneself under the substrate, making out, and mating.

Based on Fig. (5), mud crabs were steadily moving with a percentage value of 73.23 , while the moving place recorded was $26.77 \%$. The mud crab's constant movement was detected in the movement of the limbs, such as the eyes, mouth, body (back of the carapace), and claws (Fig. 6). Meanwhile, moving place was formed by walking or swimming (Fig. 7). Based on observations of seven days, the steady move of mud crab mosly moving the claws averaged $32.95 \%$, followed by moving the body (averaged $29.32 \%$ ), then moving the mouth (averaged $21.26 \%$ ), and moving the eyes (represents 16.47\%), respectively (Figure 8). 
Moving the claws recorded the highest frequency because the claws are essential parts that support the body in its movement. The next activity was moving the body; mud crab tends to move their bodies when the resting conditions are not suitable and to avoid other individuals.

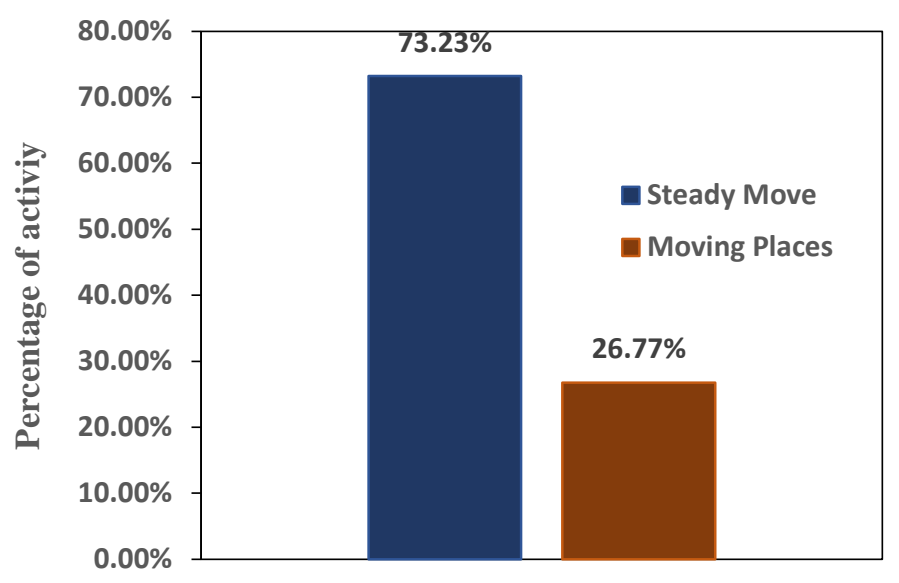

Fig. 5. Percentages of total moving activity of mud crab.

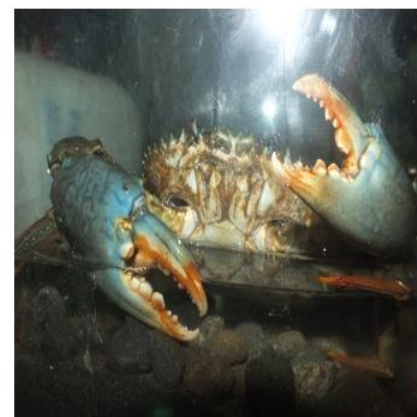

A

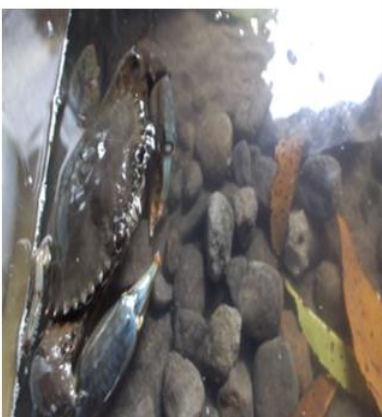

B

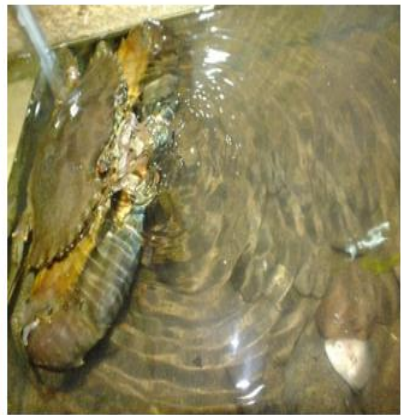

C

Fig. 6. Steady move: A. claw, B. body, C. mouth.

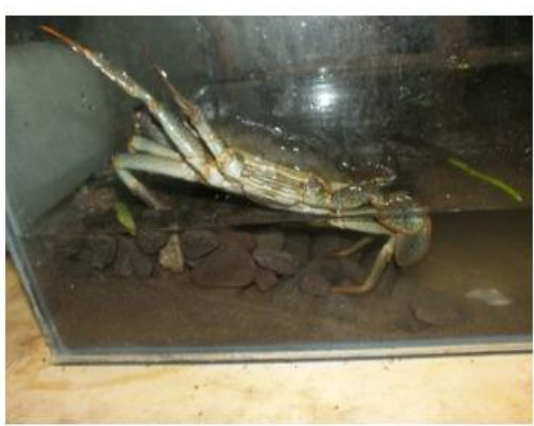

A

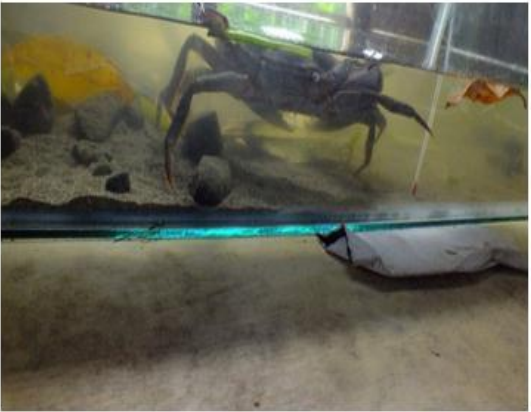

B

Fig. 7. Moving place: A. walking, B. swimming. 
According to Innocenti et al. (1998), moving the mouth to breathe is often done if there is a sudden change in water salinity. Furthermore, the mouth's movement is carried out as a greeting to the partner and cleaning the front of the body; namely, the head and the muzzle, and wiping the mouth by delousing after feeding.

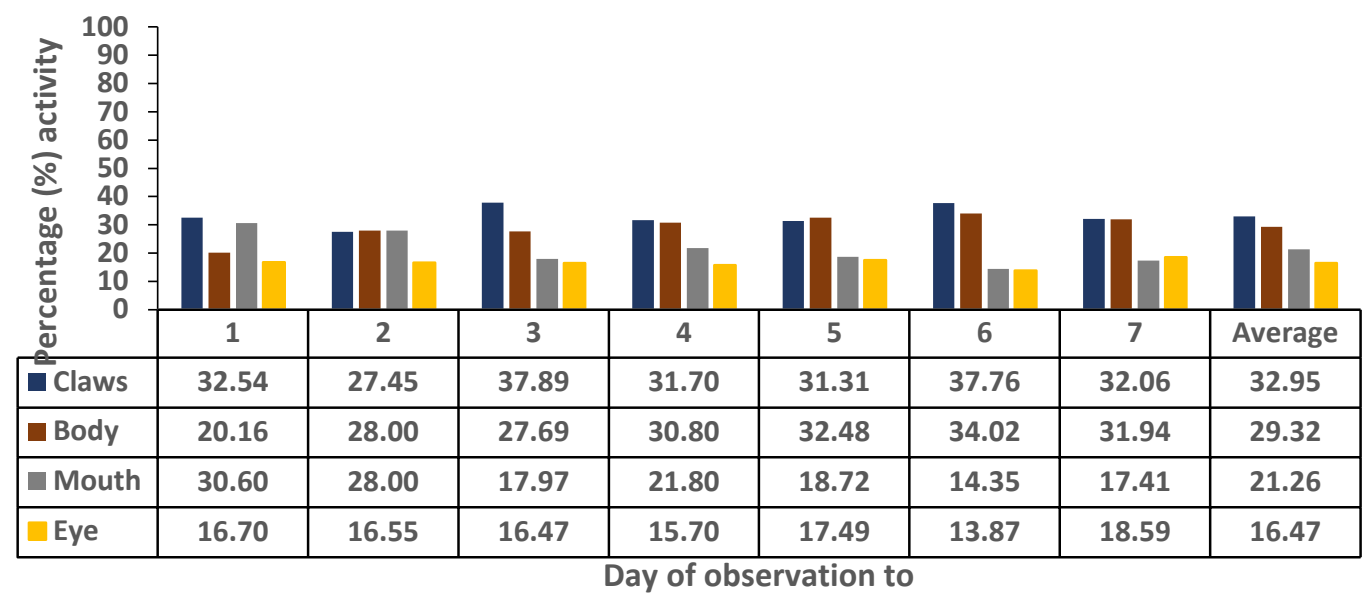

Fig. 8. Percentages of steady move activity every day observation.

The activities of the moving place were determined by walking or swimming. The mud crabs walk using claws and swim using swimming legs. Because the mud crabs were kept in a limited rearing container for unrestricted movement, the mud crabs moved more in place than moving place.

In natural habitats, when mangrove crabs move places for long distances, swimming is observed, while for short distances, in a short time and in situations that are not dangerous, moving places are done by walking (Wilber, 1986; Bergamo et al., 1988).

In addition, mud crabs move by walking or swimming when disturbed by other crabs and search for a suitable position to rest again. It was noticed that, the mud crab walked by the body tilted, and the legs tended to be raised to the wall of the maintenance container first, then dropped into the water, then were observed walking with three pairs of walking legs. Yulita (2011) stated that, the oblique body position is related to the position and the hingetype appendage joint that covers it. While moving by swimming, the body and head position is straightforward as the swimmer pedals and pushes the body to move.

According to Yulita (2011), a similar way of walking and swimming is also found in most crabs and other Brachyura. Some of them are Menippe mercenaria (Wilber, 1986), Portunus sanguinolenthus (Dinakaran \& Soundarapandian, 2009). The same behavior was applied to Thalamita danae (Cheung et al., 2004). Decapoda carried out shifting activities to avoid the arrival of a light source and find a burial place more conducive to rest (Clark, 1997).

\section{Agonistic Activity}

Remarkably, four agonistic behaviors were detected for mud crabs during the seven days of research: wrestling, opening the mouth, hunting, and biting (Fig. 9). The highest wrestling activity occurred on the fifth day when BM crab (big male) chose the mud crab BF 
(big female) to be its partner. Fig. (10) shows the agonistic activities of mud crab represented by the fighting activity to over the place and the fighting activity in protecting a partner. The intense competition between individuals would happen if ever ignition sources like mating occured (Emlen \& Oring 1977; Yulita 2011).

During the observation, mud crabs were found fighting over their resting place. The mud crabs that initially occupied the sandy substrate would be disturbed by other crabs who wanted to occupy the substrate, so the mud crabs kept fighting until one of them surrendered. Those fights occurred not only between male mud crabs but also between female mud crabs. According to Huntingford and Turner (1987), Harvey and Bradburry (1991) and Wortham and Jedlicka (2019), agonistic behavior is generally found between males and males but may also occur between females and females.

According to Bergamo et al. (1988), swimming crab behavior generally consists of several stages or elements; namely, (1) approach / AP / approach the opponent, such as moving towards the opponent; (2) alarm and stay / ALST / signals and stops suddenly including stopping movement by gripping the claw, walkway into the substrate and developing the claws; (3) alarms and approaches /ALAP/signals and approaches the opponent, including approaching the opponent with his claws still swollen; (4) contact $/ \mathrm{CO} /$ contact with the opponent, carried out using claws. Contact with claws includes touching an opponent, grasping or gripping the opponent; (5) take food / FG / grab feed from around; (6) seizing feed from the opponent / FGO / seizing the feed from the opponent by drawing the feed that has been held. However, based on the current observations, mud crabs did not engage in snatching feed from their opponents.

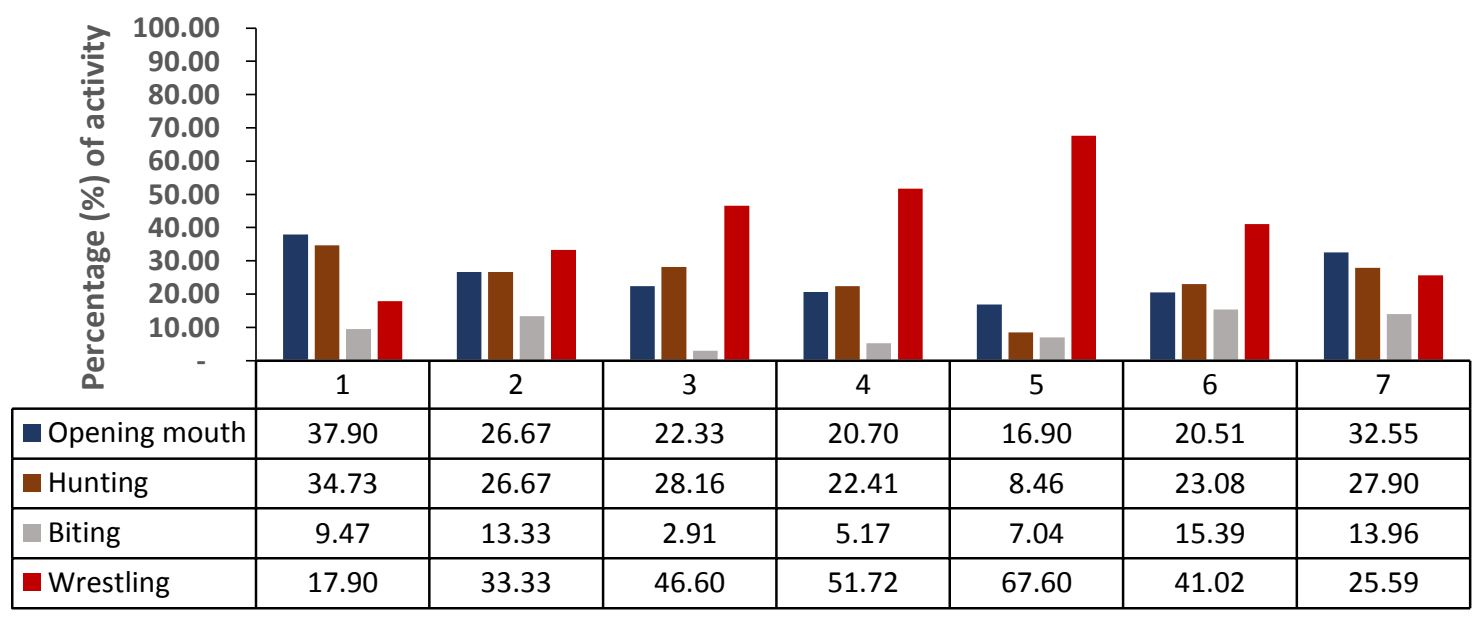

Day of observation to-

Figure 9. Percentage of agonistic activities of mud crab every day. 


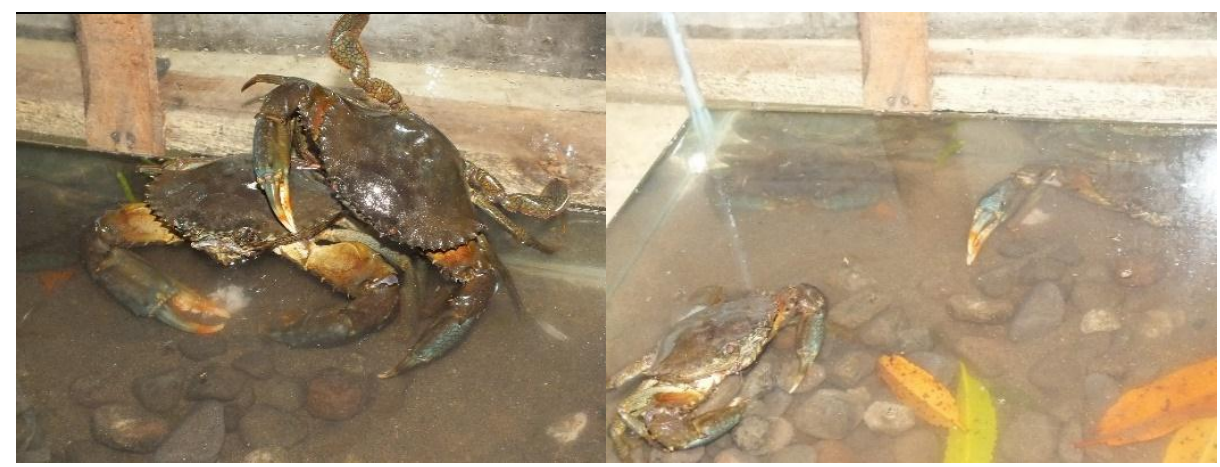

Figure 10. Agonistic activities: (A) the fighting activity over the place, (B) the fighting activity in protecting a partner

Based on each observation time (Figure 11) it can be seen that, a series of agonistic activities occurred at any time while it increased from the afternoon and until the evening. Agonistic activities were carried out to completion (the four activities) or simply did some agonistic categories (without wrestling). If done after completion, the attack occurred and ended with fighting and wrestling.

Based on the frequency of agonistic activity at every hour of observation, no agonistic activities wasdetected from morning to evening (09.00 am $-0.2 .00 \mathrm{pm})$ because they got more rest. On the other hand, they began to carry out agonistic activities in the late afternoon until early morning $(05.00 \mathrm{pm}$ to $05.00 \mathrm{am})$. At night, the big male mud crab (BM) was always ready to fight with the small male mud crab (SM). However, SM did not mean to bother the big female (BF). BM will attack by opening its claws as wide as possible when $(\mathrm{SM})$ passes $(\mathrm{BF})$.

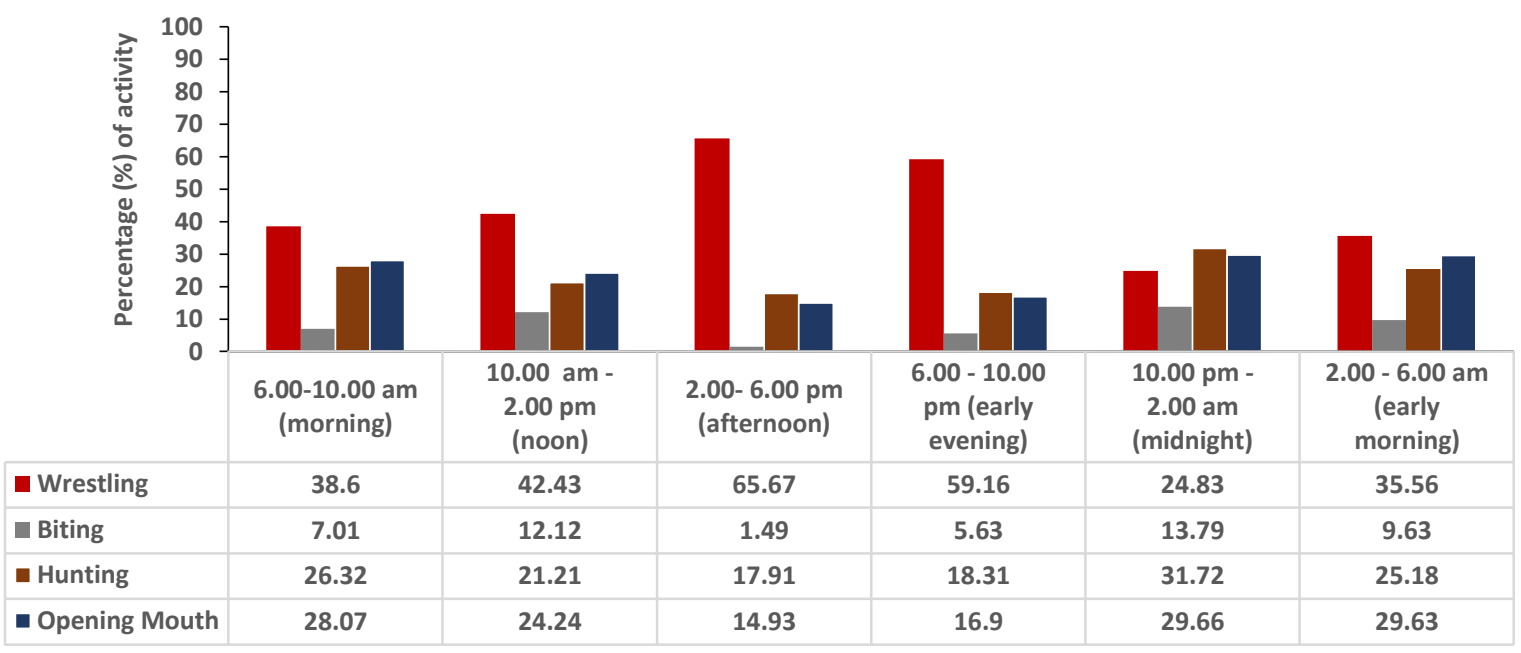

Figure 11. Percentage of agonistic activity of the mud crab every hour. 


\section{Feeding Activity.}

The highest frequency of the feeding activity of the mud crabs occurred at 6.00-10.00 $\mathrm{pm}(30.34 \%)$, at 2.00-6.00 am (29.82\%), at $10.00 \mathrm{pm}-2.00 \mathrm{am}(24.94 \%)$, at $6.00-10.00 \mathrm{am}$ $(14.90 \%)$, and $10.00 \mathrm{am}-6.00 \mathrm{pm}(0.00 \%)$, respectively (Fig. 12). This shows that the feeding activity of mud crab generally occurred after midnight (nocturnal). According to Kasry (1991) and Supadminingsih et al. (2016), the time to feed crab is irregular, but there seems to be more activity at night than during the day. These living habits enable the mud crab to detect certain foods using their olfactory organ and eyes. These results are supported by Hallberg and Skog (2011) and Frenkel et al. (2012) stating that, the visual organs of fish that live in the aphotic zone can still be used up to a certain threshold if, beyond the vision threshold, the olfactory organ plays a more critical role.

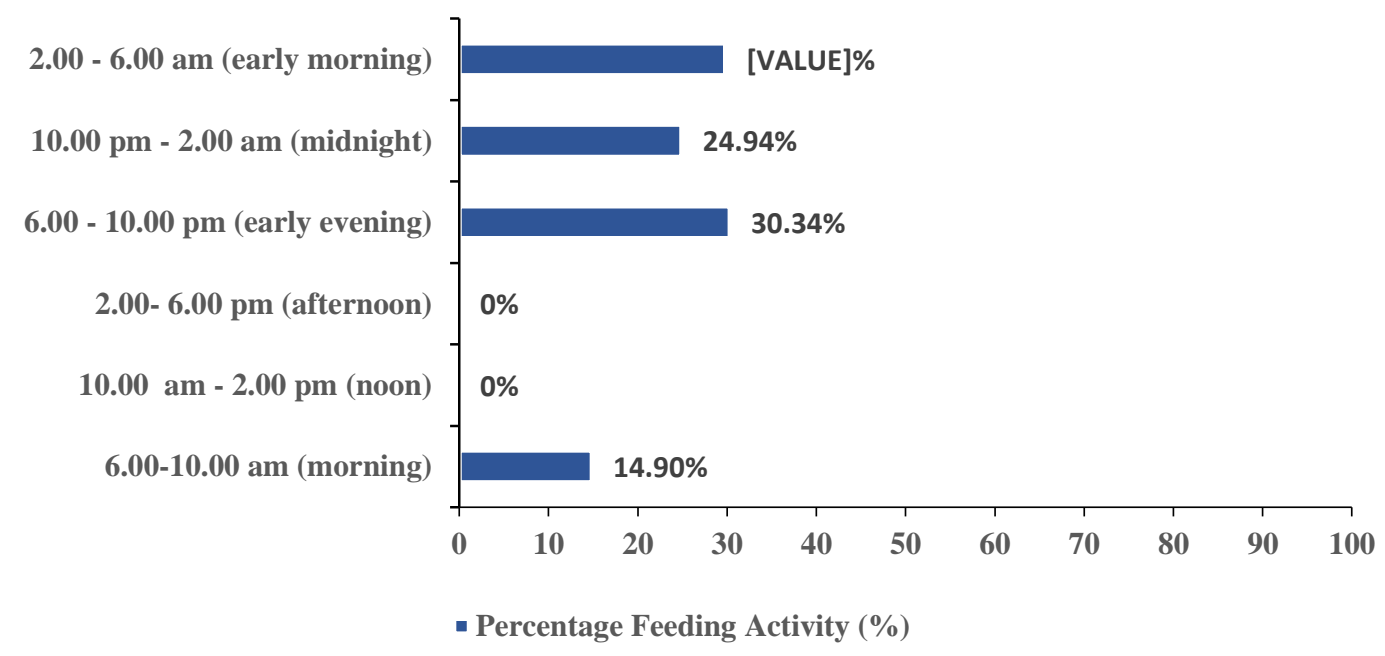

Fig. 12. Percentage feeding activity $(\%)$ of the mud crab every hour.

All mud crab feeding activities are shown in Fig. (13). The mud crabs ate a piece of feed (pieces of fresh-cut fish with a size of $1-3 \mathrm{~cm}$ ) by catching and holding with both claws; the left claw was used for cutting while the right claw for holding. Pieces of fish were put into the mouth and then bitten slowly, chewed, and swallowed until finished. Before the feed was eaten and finished, the mud crab did not take other feed. To consume their feed, mud crabs required a long time between 10 - 30 minutes. The mud crab finished its feed by hiding somewhere and always be aware of its surroundings. It was a strategy to avoid predators. Bergamo et al. (1988) reported that most Brachyura more like hiding places to limit the risk of disturbing or become prey. 


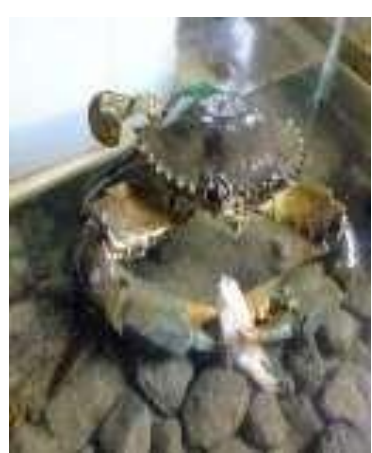

A

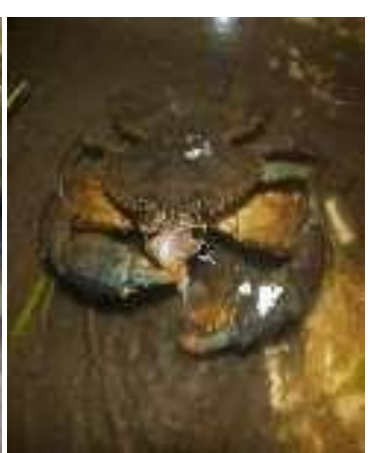

B

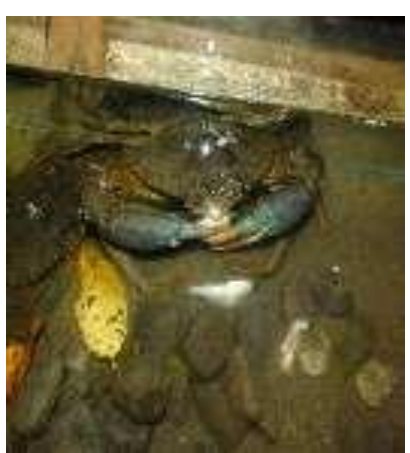

C

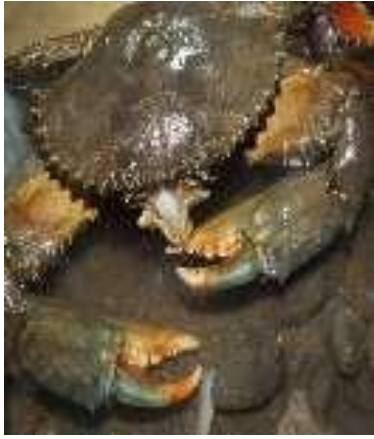

D

Fig. 9. Feeding activity of the mud crab; (A) Catching, (B) Put feed into the moth, (C) chewed, and (D) Swallowed.

\section{Physical and chemical factors}

Table (2) shows that the average of water temperature media during this study was $24.82 \pm 0.45^{\circ} \mathrm{C}$ and was still considered suitable for the life and growth of mud crab. Base on Kasry (1991), Zakaria et al. (2016) and Zeswita et al. (2016), the optimum water temperatures for mud crab life and organisms that live in the sand of the beach are $18-32{ }^{\circ} \mathrm{C}$. The lower or higher water temperatures compared to their optimum growth temperature can cause them to die.

The average salinity of research media was still classified as usual and still supports the life of mud crabs with a value of $10.80 \pm 0.87 \mathrm{ppt}$ (Table 2). Gunarto (2002) reported that, the cultivated mud crabs can grow well up to $0.62 \mathrm{~g} /$ hour at salinity of $20-25 \mathrm{ppt}$, but the growth rate was declined to $0.56 \mathrm{~g} /$ hour at salinity of $15-20 \mathrm{ppt}$, and showed furher decline to a value of $0.41 \mathrm{~g} /$ hour at salinity of $10-15 \mathrm{ppt}$.

The research media's average $\mathrm{pH}$ was also relatively good and supported mud crab growth with a value of $7.42 \pm 0.65$ (Table 2 ). The values of suitable $\mathrm{pH}$ for growth mud crab are in the range of 6.5-7.5 (Ghufron and Kordi, 2005).

Table 2. The average measurement of physical and chemical factors on behavior observation and daily activity of mud crab.

\begin{tabular}{lc}
\hline \multicolumn{1}{c}{ Parameters } & Means $(\mathrm{n}=168) \pm \mathrm{Sd}$ \\
\hline Temperature $\left({ }^{\circ} \mathrm{C}\right)$ & $24.82 \pm 0.45$ \\
Salinity $(\mathrm{ppt})$ & $10.80 \pm 0.87$ \\
$\mathrm{pH}$ & $7.42 \pm 0.65$ \\
\hline
\end{tabular}

\section{CONCLUSION}

Based on the results and discussion which are described above, it can be concluded:

(1) The behavior and daily activities of mud crab were resting, then followed with movement, agonistic activity, and feeding, respectively.

(2) Reproduction activity was not found until copulation.

(3) Mud crab was a nocturnal animal, their daily behavior was mostly done at night. 


\section{ACKNOWLEDGMENTS}

The authors thank the Rector and Head of Research Institution and Community Service (HRICS) of Andalas University to give the opportunity and approval for funding this research. This research was funded by the grant of Andalas University, moderated by Research-Publication Cluster Grant Acceleration into Professorial Tenure (Batch 1), Fiscal Year 2021with Contract Number (No). T/1/UN.16.17/PP.Pangan-PTU-KRP2GB-Unand/LPPM/2021 (fees for prepare and publication).

\section{REFERENCES}

Bergamo, P.; Flurito, G. and Miralto, A. (1988). An analysis of the agonistic behavior of Carcinus mediterraneus (Czerniavsky) (Crustecea Decapoda): fighting and ritualization. J. Monit. Zool. Ital. (N.S), 22(3): 315-322.

Catacutan, M.R. (2002). Growth and body composition of juvenile mud crab, Scylla serrata, fed different dietary protein and lipid levels and protein to energy ratios. Aquaculture, 208(1-2): 113-123.

Cheung, S.G.; Lam, S.; Gao, Q.F.; Mak, K.K. and Shin, P.K.S. (2004). Induced antipredator responses of the green mussel, Perna viridis (L.), on exposure to the predatory gastropod, Thais clavigera Küster, and the swimming crab, Thalamita danae Stimpson. Mar. Biol., 144(4): 675-684.

Cholik, F. (1999). Review of Mud-Crab Culture Research in Indonesia. In Mud Crab Aquaculture and Biology. Proc. Aus. ACIAR., 78p.

Clark, R. A. (1997). Dimorphic Males Display Alternative Reproductive Strategies in the Marine Amphipod Jasa marmorata Holmes (Corophioidea: Ischyroceridae). Ethology. 103: 531-553.

Cristensen, S.M.; Macintosh, D.J. and Phuong, N.T. (2004). Pond production of the mud crabs Scylla paramamosain (Estampador) and S. olivacea (Herbst) in the Mekong Delta, Vietnam, using two different supplementary diets. Aqua. Res., 35: 1013-1024.

Christy, J.H. (2007). Predation and the reproductive behavior of fiddler crabs (genus Uca). In: Dufy JE, Thiel M (eds) Evolutionary ecology of social and sexual systems, crustaceans as model organisms. Oxford University Press, Oxford, pp 211-231.

Dinakaran, G.K. and Soundarapandian, P. (2009). Mating behaviour and broodstock development of commercially important blue swimming crab, Portunus sanguinolentus (Herbst). Indian Journal of Science and Technology, 2(4): 71-75.

Efrizal, E. (2009). Observations on oviposition period and multiple spawning of blue swimming crab, Portunus pelagicus (Linnaeus,1758) under laboratory conditions. Indonesia. Biospectrum, 5(1): 31-37.

Efrizal, E.; Zakaria, I.J.; Rusnam, R.; Suryati, S. and Yolanda N. (2018). Studies on biological test of formulated diets supplementation of vitamin $\mathrm{E}$ for the broodstock of females blue swimming crab, Portunus pelagicus (Linnaeus, 1758). F1000 Research, 7:1780.

Emlen, S.T and Oring, L.W. (1977). Ecology: sexual selection and the evolution of mating system. J. Science, 197: 223-245.

Frenkel, L.; Dimant, B.; Suarez, L.D.; Portiansky, E.L. and Lorenzo, A. (2012). Food Odor, Visual Danger Stimulus, and Retrieval of an Aversive Memory Trigger 
Heat Shock Protein HSP70 Espression in the Olfactory Lobe of the Crab. Laboratory de Neurobiological de la Memoria. Universidad de Buenos Aires. Argentina.

Gufron, M. and Kordi, H. (2005). Aquaculture of crabs and bandeng fish on polyculture system of fishpond. Dahara Prize. Semarang. 272 p.

Gunarto, G (2002). Aquaculture of mud-crab (Scylla serrata Forskal) on fishpond. Balai Penelitian Budidaya Pantai. Maros., 134 p.

Hallberg, E. and Skog, M. (2011). Chemosensory sensilla in crustaceans. In: Breithaupt T. \& Thiel M., editors. Chemical communication in crustaceans. New York: Springer; 2011. pp. 103-121.

Harvey, P.H and Bradburry, P.H. (1991). Sexual Selection. In: Behavioral Ecology. An Evolutionary Approach. Eds. Krebs, J. R and Davies, N.B. Blackwell Scientifict Publ., Oxford, pp: 203-233.

Hazlett, B.A. (1972). Stereotype of agonistic movement in spider crab Microphrys bicornutus. Behavior, 1972, 42: 270- 278.

Huntingford, F.A. and Turner, A.K. (1987). Animal Conflict. Chapman and Hall; Softcover reprint of the original $1^{\text {st }}$ ed. 1987 Edition. 464pp.

Innocenti, G.; Vannini, M. and Galil, B.S. (1998). Notes on the behavior of the Portunid crab Charybdis longicollis Leene parasitized by the rhizochepalan Heterosaccus dollfusi Boschma. J. Nat. Hist., 32: 1577- 1585.

Kasry, A. (1991). Budidaya Kepiting Bakau dan Biologi Ringkas. Penerbit PT. Bhratara Niaga Meda, Jakarta., 93 p.

Layne, J.E.; Barnes, W.J.P. and Duncan, L.M.J. (2003). Mechanisms of homing in the fiddler crab Uca rapax 2. Information sources and frame of reference for a path integration system. Journal of Experimental Biology, 206: 4425-4442.

Lubis, A.S.; Zakaria, I.J. and Efrizal, E. (2021). Organoleptic, physical and chemical tests of formulated feed for Panulirus homarus enriched with spinach extract. AACL Bioflux, 14(2):866-873.

Ribeiro, P.D.; Christy, J.H; Rissanen, J.R. and Kim, T.W. (2006). Males are attracted by their own courtship signals. Behav. Ecol. Sociobiol., (2006) 61:81-89.

Schoene, H. (1968). Agonistic and sexual display in aquatic and semi-terresterial brachyuran crabs. American Zoology, 8(3): 641-654.

Supadminingsih, F.H.; Fitri, A.D.P. and Asriyanto, A (2016). The Model Movement of Mud Crab's Life Stage (Scylla serrata) in Responds to Different Food (Laboratory Scale). Saintek Perikanan, 12(1): 1-6.

Ward, T.M.; Schmarr, D.W. and McGarvey, R. (2008). Northern territory mud crab fishery: 2007 stock assessment. SARDI Aquatic Sci. Publ. No: F2007/000926- 1. SARDI Res. Rep. Ser. No.244 West Beach, South Australia.

Watanabe, S.; Sulistiono, M; Yokota and Fuseya, R. (1996). The fishing gears and methods of the mud crab in Indonesia. Cancer, (5): 23-26.

Wilber, D.H. (1986). The Distribution and daily movement of slone crabs (Mennipe mercenaria) in an intertidal oyster habitat on the nortwest coast of Florida. J. Mar. Behave. Physiol., 12: 279- 291.

Wortham, J.L. and Jedlicka, J. (2019). Grooming behaviors and fouling of the spider crab Libinia dubia (Decapoda: Epialtidae). Nauplius, 27: e2019009 (1-17) 
Yulita R. (2011). Reproduction Behavior of Portunus pelagicus in Control Condition. M.Sc. thesis (unpublished), Dept. of Biology, Univ. Andalas. Padang, Indonesia. 67p.

Zeswita, A.L.; Dahelmi; Zakaria I.J. and Salmah S. (2016). Study population of freshwater shellfish Corbicula sumatrana in Singkarak Lake West Sumatra Indonesia. Res. J. Pharm. Biol. Chem. Sci., 7(6): 1435-1441.

Zakaria, I.J.; Arma S.P. and Nurdin J. (2016). Ecology of mussel shells (Donax compressus Lamark, 1800) in Tiku Beach Agam District, West Sumatra, Indonesia. Journal of Fisheries and Aquatic Science, 11(4):255-267.

Zakaria, I.J. and Selasih, R.D. (2018). The abundance of mud crab (Scylla serrata Forskal, 1775) in Sungai Pisang mangrove forest, Padang city, West Sumatra, Indonesia. WJPLS, 4(5): 01-03. 